\title{
PANDANGAN GREG BARTON TENTANG ISLAM LIBERAL DAN EKSISTENSI POLITIK ISLAM DI INDONESIA
}

\author{
M. Syafi'i \\ Jl. Kapasari Pedukuhan III/2 Surabaya | mohsyafii234@gmail.com
}

\begin{abstract}
The Greg Barton's point of view on liberal Islam and Islamic political existence in Indonesia departs from the result of his study on liberal Muslim thinkers in Indonesia, including NurcholishMadjid and Abdurrahman Wahid. Their thoughts are classified as a liberal. Madjid, in most of his methodologies, uses a double movement, while Wahid uses a socio-cultural approach. In addition, MadjidCakNuris also known by his secularization project, while Wahidis famous by his pluralism project. Greg Barton arrived at this conclusion after reading Madjid and Wahid's opinions in books and articles. In relation to the existence of the political Islam in Indonesia, Greg Barton views that the collapse of the Islamist party of Masjumivaspartly contributed by Madjid'sliberal thought in understanding Islam. On the other hands, the appearance of religious pluralism in society, which is also a part of a liberal Islamic thought, wasexpedited by Wahid when he was a president of Indonesia.
\end{abstract}

Keywords: Islam liberal, Islamic political existence, Greg Barton

Abstrak: Pandangan Greg Barton mengenai Islam liberal dan eksistensi politik Islam di Indonesia berangkat dari hasil penelitiannya terhadap tokoh-tokoh Islam liberal yang ada di Indonesia, di antaranya Nurcholis Madjid dan Abdurrahman Wahid. Kedua tokoh tersebut merupakan sample tokoh Islam liberal yang concern dan konsisten dalam pemikirannya terhadap Islam. Pemikiran kedua tokoh tersebut berada pada jalur liberal. Cak Nur menggunakan metode Double Movement dalam kerangka berpikirnya, sedangkan Gus Dur menggunakan pendekatan sosio kultural. Cak Nur dikenal dengan sekularisasinya, sedangkan Gus Dur dikenal dengan pluralismenya. Pemikiran keduanya oleh Greg Barton digambarkan dengan beberapa karya tulis yang menggambarkan sisi sekularnya bagi Cak Nur, dan sisi pluralnya bagi Gus Dur. Dalam kaitannya terhadap eksistensi politik Islam di 
Indonesia, Greg Barton memandang bahwa runtuhnya Masyumi era Cak Nur, merupakan dampak dari pemikiran liberal Cak Nur dalam memahami Islam. Selain itu muncul nilai pluralitas yang tinggi di masyarakat, yang juga merupakan bagian dari pemikiran Islam liberal. $\mathrm{Hal}$ ini dilakukan oleh Gus Dur pada masa ia menduduki pucuk pimpinan negara dan berlangsung lama meskipun ketika Gus Dur lengser.

Kata Kunci: Islam liberal, eksistensi politik Islam, Greg Barton

\section{Pendahuluan}

Islam liberal merupakan sebuah wacana yang menjadi debatable di kalangan intelektual muslim hingga kini. Secara etimologis dalam kamus Bahasa Indonesia, Islam adalah agama yang diajarkan oleh Nabi Muhammad SAW, berpedoman pada kitab suci Al-Qur'an yang diturunkan ke dunia melalui wahyu Allah SWT. ${ }^{1}$ Liberal sendiri berarti bebas, dalam artian berfikir atau berpandangan (luas dan terbuka). ${ }^{2}$ Dapat diartikan bahwa Islam liberal adalah suatu pemahaman terhadap Islam secara bebas (luas dan terbuka).

Dalam artian secara literal, label Islam liberal dianggap sebagai suatu pemikiran separatis terhadap Islam yang akan merubah paradigma yang ada bagi kalangan Islam tradisionalis dan radikal khususnya. ${ }^{3}$ Pemikiran Islam yang diklaim seperti tersebut sebelumnya itu didasarkan atas karya-karya yang dipublikasikan oleh kalangan Islam liberal, berupa artikel, opini, argumentasi, dan karya tulis baik dalam bentuk buku maupun karya-karya ilmiah lainnya. Sebagai contoh Jaringan Islam Liberal (JIL) misalnya, sebuah komunitas yang tergabung dalam sebuah wadah berisikan tokoh-tokoh intelektual dengan pemikiran liberalnya yang bernama komunitas utan kayu (awalnya). Kemunculan JIL ini menambah sempit image publik terhadap

I Pusat Bahasa Departemen Pendidikan Nasional, Kamus Besar Bahasa Indonesia, (Jakarta: Balai Pustaka, 2005), Cet. III, 444.

${ }^{2}$ Ibid., 668.

${ }^{3}$ Muhammad Asfar, Islam lunak dan Islam radikal, 74. 
Islam liberal. Sebab, kebanyakan tokoh-tokoh yang ada di dalamnya, banyak memugar pemahaman terhadap Islam dalam masyarakat yang telah menjadi doktrin publik, bahwa Islam merupakan agama yang paling benar, namun JIL berkata tidak. Maka dari itulah masyarakat mulai menyimpulkan Islam liberal dengan simpul yang negatif, yang menganggap bahwa Islam liberal telah keluar dari rel syari'at, meskipun tidak seluruhnya orang Islam mengatakan demikian. Adapun berbagai opini dan pemahaman yang disuguhkan oleh tokoh-tokoh pemikir JIL kepada masyarakat luas umumnya adalah seperti pendapat Ulil Abshar Abdallah sebagai koordinator JIL "Tapi bagi saya, all scriptures are miracle, semua kitab suci adalah mu'jizat." 4

Kemudian Luthfi Assyaukanie; sebagian besar kaum muslim meyakini bahwa Al Qur'an dari halaman pertama hingga terakhir merupakan kata-kata Allah yang diturunkan kepada Nabi Muhammad SAW secara verbatim, baik kata-katanya (lafdzan) maupun maknanya (ma'nan). Kaum muslim juga meyakini bahwa Al Qur'an yang mereka lihat dan baca hari ini adalah sama persis seperti apa yang ada pada masa Nabi lebih dari seribu empat ratus tahun silam. Keyakinan semacam itu sesungguhnya lebih merupakan formulasi dan angan-angan teologis (al-khayal al-dini) yang dibuat oleh para ulama sebagai bagian dari doktrin-doktrin Islam. Hakikat dan sejarah penulisan Al-Qur'an sendiri sesungguhnya penuh dengan berbagai nuansa yang delicate (rumit), dan tidak sunyi dari perdebatan, pertentangan, intrik (tipu daya), dan rekayasa. ${ }^{5}$

Dan masih begitu banyak statemen yang ditawarkan oleh JIL kepada masyarakat umum, sehingga wajar jika publik banyak mengklaim JIL dengan hal-hal negatif. Namun, dari berbagai sudut pandang tentang Islam liberal, ada sebuah pandangan baru yang muncul dari seorang Greg Barton.

${ }^{4}$ http://www.arrahmah.com/index.php/blog/read/I 376/liberalisasi-Islam-di-Indonesia

${ }^{5}$ lbid. 
Dr. Greg Barton (selanjutnya disebut Dr. Greg) merupakan salah seorang professor di Universitas Monash (Melbourne, Australia). ${ }^{6}$ Ia dikenal sebagai seorang professor, dan pengajar yang ahli dalam bidang politik di Universitas Deakin (Melbourne, Australia, 1993-2003). ${ }^{7}$ Ketertarikannya terhadap Islam di Indonesia begitu kuat, sehingga Dr. Greg bersedia tinggal lebih lama di Indonesia untuk melakukan risetnya terhadap Islam dan politik di Indonesia. Cukup lama ia tinggal di Indonesia mulai tahun 1980-an hingga 1990-an bahkan lebih, hanya untuk menuntaskan risetnya terhadap Islam di Asia, khususnya Indonesia, khususnya tentang Islam liberal. ${ }^{8}$ Ia dijuluki seorang ahli politik Islam karena kurun waktu tinggal yang cukup lama di Indonesia, untuk mempelajari perkembangan politik di Indonesia, khususnya politik Islam.

Pandangan Dr. Greg tentang Islam liberal berbeda dengan pandangan pengamat pada umumnya, kebanyakan pengamat lainnya memandang Islam liberal dari sisi pemikiran an sich. Berbeda dengan Dr. Greg, pengamatannya terhadap pemikiran Islam liberal di Indonesia tidak terbatas dari sudut pandang pemikiran saja. Namun, juga membahas tentang implikasi pemikiran Islam liberal terhadap politik Islam di Indonesia. Perbedaan sudut pandang ini terlihat dari penelitiannya terhadap Islam di Asia, khususnya Indonesia dalam mengamati perkembangan politik Islam. Tak heran jika oleh sebagian orang, ia dijuluki sebagai ahli politik Islam, khususnya di Indonesia, salah seorang tersebut adalah Wimar Witoelar. Pada saat itu Dr. Greg menghadiri acara talk show yang diadakan oleh Wimar, dalam acara perspektif Wimar pada tanggal 22 mei 2008.

Seorang Wimar menyebut Dr. Greg sebagai ahli politik Islam, karena pandangannya yang begitu berbeda dalam mengamati

\footnotetext{
${ }^{6} \mathrm{http}: / / \mathrm{mw}$.apcss.org/core/bios/barton/barton.htm

$7 \mathrm{lbid}$.

${ }^{8}$ Greg Barton, Biografi Gus Dur: The Authorized Biography of Abdurrahman Wahid, terj. Lie Hua, (Yogyakarta: LkiS, 2006), x.
} 
Islam dan politik Islam di Indonesia. ${ }^{9}$ Dalam talk show itu Dr. Greg sempat mengatakan bahwa; "Indonesia adalah jendela yang bagus untuk melihat Islam secara utuh. Tapi dalam konteks kekinian, Islam sering dipakai untuk komoditas politik karena mayoritas banyak umat Islam yang miskin."10

Perhatian Dr. Greg terhadap politik Islam di Indonesia berawal dari ketertarikannya terhadap sosok Gus Dur dan Cak Nur. Sehingga, ia melakukan riset yang memfokuskan obyek kajiannya terhadap dua tokoh ini. Tidak hanya dua tokoh tersebut, akan tetapi masih ada dua tokoh lainnya yang ia teliti dalam disertasi doktoralnya yang berjudul "Gagasan Islam Liberal di Indonesia: Pemikiran Neo-Modernisme Nurcholis Madjid, Djohan Effendi, Ahmad Wahib, dan Abdurrahman Wahid" judul disertasi tersebut merupakan terjemahan dari disertasi Greg yang telah dibukukan, dengan judul asli "The Emergence of Neo-Modernism: Progessive, Liberal, Movement of Islamic tought in Indonesia: A Textual Study Examining the Writing of Nurcholis Madjid, Djohan Effendi, Ahmad Wahib, dan Abdurrahman Wahid."11

Berangkat dari tokoh yang diteliti oleh Dr. Greg, penulis memfokuskan penelitian terhadap pandangan Greg Barton pada dua tokoh pemikir Islam liberal, yaitu Nurcholis Madjid dan Abdurrahman Wahid tentang Islam liberal dan eksistensi politik Islam di Indonesia. Karena, penulis menganggap ada suatu kesamaan pada pola pikir dan sepak terjang di dunia politik antara satu sama lain.

\section{Ruang Lingkup Sosial Nurcholis Madjid Menurut Pandangan Greg Barton}

\footnotetext{
${ }^{9} \mathrm{http}: / / \mathrm{ww}$.perspektif.net/article.php?article id $=885$

${ }^{10} \mathrm{lbid}$.

"Ahmad Suaedy dan Ulil Abshar Abdalla (eds), Gila Gus Dur: Wacana Pembaca Abdurrahman Wahid, (Yogyakarta: Lkis, 2000), 21 I.
} 
Penarik gerbong Islam Liberal pertama terdiri dari empat tokoh diantaranya Nurcholis Madjid, Djohan Effendi, Ahmad Wahib, Dan Abdurrahman Wahid. ${ }^{12}$ Keempat tokoh ini menurut Greg Barton, Ph.D., (selanjutnya disebut Dr. Greg) dosen Melbourne University, dalam disertasinya adalah tokoh pemikir Liberal atau "pembaharu pemikiran Islam" di Indonesia. ${ }^{13}$

Dr. Greg mengangkat keempat tokoh ini dalam sebuah disertasi doktoralnya di Monash University dengan judul "Gagasan Islam Liberal di Indonesia: Pemikiran Neo-Modernisme Nurcholis Madjid, Djohan Effendi, Ahmad Wahib, dan Abdurrahman Wahid" judul disertasi tersebut merupakan terjemahan dari disertasi Greg yang telah dibukukan, dengan judul asli "The Emergence of Neo-Modernism: Progessive, Liberal, Movement of Islamic tought in Indonesia: A Textual Study Examining the Writing of Nurcholis Madjid, Djohan Effendi, Ahmad Wahib, dan Abdurrahman Wahid."14 Greg mencoba memadukan pemikiran keempat tokoh tersebut yang dianggap memiliki gagasan yang sama terhadap pembaharuan pemikiran Islam dengan mengusung Islam Liberal sebagai motor penggeraknya.

Dr. Greg melihat Islam liberal dengan berkaca kepada dua tokoh pemikir Islam liberal yaitu Nurcholis Madjid (selanjutnya disebut Cak Nur) dan Abdurrahman Wahid (selanjutnya disebut Gus Dur) serta pemikir Islam liberal lainnya kaitannya dengan penelitiannya di Indonesia. Menurut Dr. Greg Cak Nur merupakan salah seorang cendikiawan besar Islam pada periode modern, alasannya pemikiran Cak Nur yang begitu jernih, tegas, cukup luas, dan sangat menguasai sejarah tentang Islam. ${ }^{15}$ Selain itu, Dr. Greg kagum terhadap kepribadian Cak Nur yang terhormat dan sangat ramah terhadap semua orang, bahkan

\footnotetext{
${ }^{12} \mathrm{http}: / /$ www.allslamu.com/index.php?option $=$ com_content\&task=view\&id $=4 \mid$ \&itemid $=10$

$13 \mathrm{lbid}$.

${ }^{14}$ Ahmad Suaedy dan Ulil Abshar Abdalla (eds), Gila Gus Dur: Wacana Pembaca Abdurrahman Wahid, 211.

${ }^{15}$ http://www.harianterbit.com/artikel/rubrik/artikel.php?aid=6447 I
} 
terhadap orang-orang yang memusuhi dan memfitnahnya, sampai-sampai Dr. Greg memberikan pujian terhadap sosok Cak Nur sebagai "Being truly saintly and Godly charachter."16

Cak Nur lahir di Jombang, Jawa Timur, pada tanggal 17 Maret 1939, masa kecilnya dihabiskan di Denanyar, ayahnya bernama Abdul Madjid bukanlah seorang kiai seperti pada umumnya, ayahnya hanya seorang petani miskin yang merupakan penganut Masyumi. ${ }^{17}$ Masa kecilnya, Cak Nur mengenyam pendidikan di pesantren Darul Ulum Rejoso, Jombang, Jawa Timur, pada tahun1955, kemudian melanjutkan pendidikannya di pesantren Darul Salam, Gontor, Ponorogo, Jawa Timur 1960. Melanjutkan perguruan tinggi di luar negeri atas rekomendasi dari pondok pesantren gontor untuk menerima beasiswa yang diberikan oleh Institut Agama Islam Negeri (IAIN), Syarif Hidayatullah, Jakarta, 1965 (BA, Sastra Arab). Selain meneruskan di jurusan sastra arab, Cak Nur juga melanjutkan di Institut Agama Islam Negeri (IAIN), Syarif Hidayatullah, Jakarta, 1968 (Doktorandus, Sastra Arab), setelah itu Cak Nur mengambil beasiswa di The University of Chicago (Universitas Chicago), Chicago, Illinois, USA, 1984 (Ph.D, Studi Agama Islam) atas permintaan IAIN Syarif Hidayatullah dengan rekomendasi dari pondok pesantren Modern Gontor, bidang yang diminati oleh Cak Nur Filsafah dan Pemikiran Islam, Reformasi Islam, Kebudayaan Islam, Politik dan Agama Sosiologi Agama, Politik negara-negara berkembang. ${ }^{18}$

Karena lingkungan dan latar belakang seperti itulah, sehingga Dr. Greg menyimpulkan bahwa hal tersebut yang melatar belakangi pemikiran liberal Cak Nur. Terlebih ketika masih mahasiswa, Cak Nur menduduki jabatan tertinggi di HMI, selain itu Cak Nur juga merupakan salah satu anak didik atau memiliki senior seorang Muhammad Natsir. Namun dalam perjalanannya

\footnotetext{
16 Ibid.

${ }^{17}$ Greg Barton, Biografi Gus Dur, The Authorized Biography of Abdurrahman Wahid, 139.

${ }^{18}$ http://www.tempointeraktif.com/hg/narasi/2004/05/30/nrs,20040530-05,id.html
} 
Cak Nur begitu menyimpang dari apa yang dilakukan oleh Muhammad Natsir selaku petinggi Masyumi.

\section{Metode Pemikiran Nurcholis Madjid Menurut Pandangan Greg Barton}

Barton mengatakan, Nurcholis Madjid tidak diasingkan lagi sebagai salah satu pemikir modern dalam wacana pemikiran Islam di Indonesia. ${ }^{19}$ Kehadirannya mampu mendobrak tatanan baru pola pemikiran Islam dengan menghadirkan suasana baru ketika berhadapan dengan teks-teks Islam. Pemikiran Cak Nur ini banyak dipengaruhi oleh pendahulunya seperti Mukti Ali, Deliar Noer, Harun Nasution, dan pemikir terkemuka Masyumi, Mohammad Natsir. Suatu kesalahan besar jika orang mengatakan bahwa pemikirannya itu berangkat dari kekosongan (ex Nihilo), sebab terlihat jelas dari sejarahnya, ia banyak mengikuti alur pemikiran pendahulunya.

Sejak remaja pemikirannya begitu kritis dan dapat dikatakan berbahaya, itu sedikit terlihat dengan hasil karyanya yang berbentuk buku kecil yang diberi nama Nilai-nilai Dasar Perjuangan (NDP), yang digunakan sebagai pedoman ideologis HMI. ${ }^{20}$ Pemikiran Cak Nur mengalami perubahan pasca menyelesaikan studi di Amerika tepatnya di Chichago. Perkembangan pemikirannya yang begitu cepat selangkah lebih maju akibat pengaruh iklim pemikiran Amerika Serikat. Diawal tahun yaitu sekitar tahun 1970-an tepatnya tanggal 3 januari 1970, titik perubahan pola pikirnya mulai terlihat dengan diwujudkan melalui pidato intelektualnya pada seminar 3 Januari 1970. Pasca itu istilah-istilah "berbahaya" yang digunakan Cak Nur secara telanjang dan berani, dan publikasi besar-besaran melalui media masa. ${ }^{21}$

${ }^{19}$ Greg Barton, Gagasan Islam Liberal di Indonesia, (Jakarta: Paramadina, 1999), 71.

${ }^{20} \mathrm{lbid} ., 8 \mathrm{l}$.

${ }^{21}$ Ibid., 82. 
Pada saat itu Cak Nur dikenal sebagai pembaharu pemikiran Islam dengan beberapa konsep pemikirannya, yang ia coba untuk tawarkan pada masyarakat umum. Beberapa gagasan yang ia tawarkan tersebut banyak menuai kontroversi. Dalam hal ini, gagasan-gagasan yang tersebut sebelumnya merupakan hasil kajian mendalam dari Cak Nur terhadap Islam dengan mengaju pada al-Qur'an sebagai sumber dasar pemikirannya.

Metode yang digunakan oleh Cak Nur adalah Double Movement yaitu secara bahasa berarti perpindahan ganda dalam hal ini yaitu perpindahan dari situasi sekarang ke situasi turunnya wahyu, lalu kembali lagi ke masa kini untuk menggali relevansi ajaran agama. ${ }^{22}$ Sehingga tidak mengherankan kalau terkadang gagasannya begitu menukik tajam menguak tabir Islam.

\section{Pola Pikir Nurcholis Madjid Menurut Pandangan Greg Barton}

Cak Nur pada saat itu menjadi pusat kontroversi dalam tataran politik Islam di Indonesia, karena gagasan-gagasannya yang begitu keras menyimpang dengan cita-cita politik Islam pada masa itu. Cita-cita politik Islam dimaksud adalah, terwujudnya formalisasi syari'at dalam sebuah konstitusi negara (Indonesia). Pada saat itu yang begitu gencar menggembar-gemborkan formalisasi syari'at adalah sekelompok Masyumi, namun pada akhirnya Masyumi sendiri tergilas oleh waktu yang juga merupakan efek dari gagasan-gagasan Cak Nur.

Salah satu hal yang menuai kontroversi begitu keras terhadap Cak Nur menurut Dr. Greg adalah pidatonya pada acara silaturahmi akhir Ramadhan januari 1970.23 Cak Nur membacakan makalahnya yang telah dipersiapkan dengan baik dan dengan keras meminta agar cendikiawan muda menunjukkan keberanian yang lebih besar dan mengambil resiko yang lebih tinggi. Dengan tegas Cak Nur menyatakan:

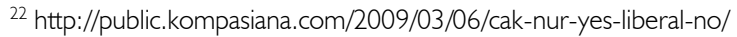

${ }^{23}$ Greg Barton, Biografi Gus Dur: The Authorized Biography of Abdurrahman Wahid, 137.
} 
Banyak cendikiawan muda Indonesia muak dengan obsesi masa lampau yang penuh kerinduan akan politik partai yang terdapat pada banyak kaum modernis Masyumi. Apa yang sebenarnya diinginkan oleh kaum Muslim muda, demikian dinyatakan oleh Nurcholis, adalah Islam, bukan politik Islam. Ia, mengajukan argumennya bahwa masyarakat Muslim di Indonesia, dan terutama pemimpin-pemimpin intelektualnya, berada dalam persimpangan jalan. Apabila mereka terus memprioritaskan persatuan umat maka hal ini berarti melanjutkan kemandekan dan kemerosotan intelektual. Alternatifnya, adalah mengambil resiko dikritik, dan bahkan mengalami perpecahan, agar dapat memajukan ide-ide baru dan mendorong timbulnya pemikiran segar dalam masyarakat Islam. ${ }^{24}$

Pidato ini menurut Dr. Greg menandai dimulainya suatu gerakan yang kemudian dikenal sebagai gerakan Pembaharu Pemikir Islam. Dari sisi inilah Dr. Greg melihat pola pikir liberal Cak Nur dalam memahami Islam, yang kemudian ditelaah lebih jauh oleh Dr. Greg dengan melihat beberapa karya yang menggambarkan pola pikir Cak Nur terkait masalah Islam liberal dan eksistensi politik Islam di Indonesia. Sebuah kerangka berpikir liberal yang ditawarkan oleh Cak Nur antara lain Modernisasi dan Sekularisasi. Dalam sejarahnya kedua konsep pemikiran Cak Nur tersebut memiliki keterkaitan terhadap eksistensi politik Islam di Indonesia. Untuk memahami lebih jauh akan modernisasi dan sekularisasi Cak Nur akan dibahas sebagai berikut:

\section{Modernisasi}

Modernisasi ialah Rasionalisasi bukan Westernisasi merupakan artikel Cak Nur yang terbagi dalam dua bagian. ${ }^{25}$ Bagian pertama berbicara mengenai pandangan progresif dalam modernisasi, dan bagian kedua mengajukan pembelaan apologetik mengenai keharusan masyarakat untuk beriman kepada Tuhan.

\footnotetext{
${ }^{24}$ lbid., 137-138

25 Ibid., 88.
} 
Sebenarnya peta pemikiran Cak Nur tentang rasionalitas telah dapat ditelusuri sejak dahulu dari konsep kebaikan dan batasanbatasan rasionalitas serta keharusan rasionalisme serta keimanan yang ia paparkan saat ia masih mahasiswa, tepatnya saat ia masih berada dalam kepengurusan HMI. Tema yang berulang-ulang tentang rasionalitas dan iman, atau ilmu dan iman, dan ruang keduanya bekerja; yaitu yang satu di dunia temporal, dan yang lainnya di dunia transendental atau ukhrawi, semuanya itu secara panjang lebar dijelaskan dalam tulisan Cak Nur pada tahun 1970an. Bahkan NDP yang menjadi pedoman ideologi HMI merupakan bagian dari pemikirannya.

Munculnya sebuah tulisan ini (modernisasi ialah rasionalisasi bukan westernisasi) adalah dimaksudkan untuk meluruskan pandangan masyarakat kala itu, yang mana banyak memperdebatkan permasalahan seputar modernisasi. Dengan anggapan bahwa umat Islam merupakan salah satu dari beberapa golongan yang menolak modernisasi, termasuk para mahasiswa Islam. ${ }^{26}$ Padahal menurut Cak Nur mahasiswa merupakan lapisan yang lebih terpelajar daripada masyarakat, sehingga kedudukan mahasiswa yang juga sering disebut sebagai "the nations best human material" itu, justru sebagai "modernizing agent." 27

Dalam sebuah pemahaman apologetik yang dipaparkan oleh Cak Nur sebagai wujud counter issue terhadap opini publik yang berkembang pada masa itu Cak Nur menyatakan;

Bagi seorang muslim yang sepenuhnya meyakini kebenaran Islam sebagai way of life, semua nilai dasar way of life yang menyeluruh itu tercantum dalam kitab suci al-Qur'an. ...Maka sebagai penganut way of life (dalam kerangka beragama "Islam"), dengan sendirinya juga menganut cara berpikir Islami. Demikianlah, dalam menetapkan penilaian tentang modernis, juga berorientasi kepada nilai-nilai besar Islam. Singkatnya ...modernisasi adalah suatu keharusan, malahan kewajiban yang

\footnotetext{
${ }^{26}$ Nurcholis Madjid, Islam Kemodernan dan Kelndonesiaan, (Bandung, Mizan, 1993), I7I.
} ${ }^{27}$ Ibid. 
mutlak. Modernisasi merupakan pelaksanaan perintah dan ajaran Tuhan Yang Maha Esa. ${ }^{28}$

Modernisasi yang dipahami Cak Nur adalah penerapan rasionalitas secara terus menerus (bukan rasionalisme dalam pandangan sekular materialistik), dan itu merupakan bagian dari pesan Islam. ${ }^{29}$ Cak Nur mengembangkan konsep kemodernannya dengan mengaitkan pada konsep tauhid. ${ }^{30}$ Hal yang ingin diperoleh dari gagasan Cak Nur di atas adalah agar setiap muslim memiliki sikap terbuka kepada setiap orang dan hal yang baru termasuk modernitas sebagaimana diperintahkan Tuhan. Namun yang lebih utama dari itu adalah bertujuan untuk mencapai kebenaran yang mutlak dan kebenaran mutlak itu sendiri merupakan Tuhan, karena merupakan awal dan akhir segala kebenaran, serta sebagai pemilik kebenaran mutlak. Sedangkan apa yang ada di dunia temporal ini (duniawiah) hanya bersifat sementara.

Cak Nur dikenal sebagai tokoh yang sangat concern dan commited terhadap berbagai persoalan kebangsaan, terutama menyangkut persoalan pluralisme bangsa dan agama. ${ }^{31}$ Tak heran jika gagasan tersebut terlontar dalam sebuah tulisannya. Dengan tujuan untuk mengaplikasikan pemikirannya itu dalam dunia politik. ${ }^{32}$

\section{Sekularisasi}

Seperti tersebut sebelumnya pembahasan ini merupakan bagian dari tulisan Cak Nur sebelumnya. Sekularisasi ini merupakan bagian dari pandangan progresif dalam modernisasi, sedangkan tersebut sebelumnya pandangan dengan pemikiran apologetik terhadap modernisasi.

${ }^{28}$ lbid., 172.

${ }^{29}$ Greg Barton, Gagasan Islam Liberal, 100.

${ }^{30}$ lbid., I0I.

${ }^{3}$ Nurcholis Madjid, Jejak Pemikiran dari Pembaharu Sampai Guru Bangsa, (Yogyakarta: Pustaka Pelajar, 2003), 392.

32 Ibid., 74. 
Sekularisasi yang dimaksud oleh Cak Nur berbeda dengan paham sekularisme. ${ }^{33}$ Menurut Barton dalam perbincangannya bersama salah seorang penganut JIL Cak Nur membedakan antara sekularisme dengan sekularisasi, sekularisme merupakan ideologi tanpa agama, sedangkan sekularisasi merupakan proses ketika pemerintah tidak perlu campur tangan terlalu dalam dalam untuk isu-isu agama. ${ }^{34}$ Hal tersebut senada dengan apa yang dipaparkan oleh Cak Nur dalam tulisannya

Jadi, sekularisasi tidaklah dimaksudkan sebagai penerapan sekularisme dan mengubah kaum muslimin menjadi sekularis. Tetapi dimaksudkan untuk menduniawikan nilai-nilai yang sudah semestinya bersifat duniawi, dan melepaskan umat Islam dari kecenderungan mengukhrawikannya. Dengan demikian, kesediaan mental untuk selalu menguji dan menguji kembali kebenaran suatu nilai dihadapan kenyataan-kenyataan material, moral ataupun historis, menjadi sifat kaum muslimin. ${ }^{35}$

Sekularisasi dipahami sebagai proses dari sebuah sistem kepercayaan. Prosesnya melibatkan transformasi kepercayaankepercayaan dan praktik lainnya ke dalam dua arah. Arah pertama ialah ke bawah dengan cara melakukan desakralisasi atau menduniawikan segala hal yang tidak suci tapi selama ini dianggap suci. Arah kedua adalah ke atas dengan mensakralkan segala hal yang benar-benar transenden, kekal dan suci. ${ }^{36}$

Pendekatan bahasa yang digunakan oleh Cak Nur dilakukan dengan menganalogikan dengan kata-kata dalam bahasa asing terutama kaidah bahasa dalam bahasa arab. Seperti pemaknaan sekularisasi Cak Nur mengatakan kepada seluruh masyarakat baik yang mendukung maupun maupun yang mengkritiknya.

Orang harus membedakan antara connotation (bahasa arab: mafhum) sekularisasi yang berarti pengetrapan sekularism dengan

\footnotetext{
${ }^{33}$ Greg Barton, Gagasan Islam Liberal, 108.

${ }^{34} \mathrm{http} / / /$ slamlib.com/id/artikel/kalau-demokrasi-matang-radikalisme-akan-ber kurang/

${ }^{35}$ Nurcholis Madjid, Islam Kemodernan dan Kelndonesiaan, 207.

${ }^{36}$ Greg Barton, Gagasan Islam Liberal, 108.
} 
kata "sekularisasi" karena konteksnya berlainan. Ibaratnya kata "socialised medicine" bukan berarti pengetrapan socialism. ${ }^{37}$

Selain itu makna sekularisasi Cak Nur juga dianalogikan dengan makna bahasa yang ada dalam al-Qur'an, sebagai contoh kata Qital. Qital yang berarti saling membunuh, tetapi inti dari perang bukanlah pembunuhan itu an sich sehingga dapat diartikan berperang adalah melakukan kejahatan pembunuhan. Maka membunuh dan membunuh mengenal tempat yang berbeda-beda yang kemudian mengakibatkan perbedaan nilai padanya, malahan nilai itu berlawanan yang satu haram yang lain wajib. ${ }^{38}$

Maksud dari analogi Cak Nur terhadap bahasa yang ada dalam al-Qur'an adalah untuk menunjukkan bahwa sekularisasi yang ia maksud dapat juga memiliki arti yang begitu variatif sama halnya dengan bahasa dalam al-Qur'an, Cak Nur mengatakan;

Demikian pula dengan istilah sekularisasi. "sekularisme" dan "sekularisasi", dalam konteks yang berbeda, akan pula terkena penilaian yang berbeda atau berlawanan: dilarang dan disuruh. Yang dilarang sudah jelas, yaitu penerapan sekularisme dengan konsekwensi penghapusan kepercayaan kepada adanya Tuhan. Sedangkan yang diperintahkan, banyak sekali. Agama Islam pun, bila diteliti benar-benar, dimulai dengan proses sekularisasi lebih dahulu. ${ }^{39}$

Singkatnya sekularisasi adalah pengakuan wewenang ilmu pengetahuan dan penerapannya dalam membina kehidupan duniawi. ${ }^{40}$

${ }^{37}$ H.M. Rasyidi, Koreksi Tehadap Nurchlis Madjid Tentang "Sekularisasi", (Jakarta: Bulan Bintang, 1972), 8.

38 lbid.

${ }^{39}$ Nurcholis Madjid, Islam Kemodernan dan Kelndonesiaan, 222.

40 Ibid, 218. 
Pemikiran Nurcholis Madjid tentang Islam Liberal dan Eksistensi Politik Islam di Indonesia Menurut Greg Barton

Islam liberal bukan suatu hal yang baru pada masa kedua pemikir tersebut sebelumnya, nama Islam liberal belum begitu terkenal, yang ada hanya sebuah gerakan yang lebih dikenal dengan pembaharuan pemikiran Islam. Tujuan dari pembaharuan pemikiran ini juga bukan karena untuk membentuk suatu komunitas tertentu yang bisa disebut komunitas Islam liberal, sebab konsep Islam liberal ini muncul setelah para pemikir ini mengemukakan gagasannya yang bisa dikatakan begitu bebas, sehingga tak heran jika masyarakat mengatakan bahwa pemikirpemikir tersebut merupakan pemikir liberal, khususnya dalam pemikiran Islam.

Para pengamat Islam baik dari dalam maupun luar negeri sangat tertarik dengan perkembangan Islam di Indonesia. Terlebih Indonesia merupakan negara yang memiliki penduduk dengan jumlah yang besar dan mayoritas masyarakatnya menganut agama Islam. Hal tersebut dikemukakan oleh Dr. Greg dalam sebuah dialog bersama Wimar Witoelar sebagai penyelengara acara yang berjudul perspektif Wimar. Selain itu Dr. Greg juga mengatakan bahwa Indonesia merupakan jendela untuk melihat Islam jauh lebih dalam dan lebih luas, dengan alasan tersebut Dr. Greg mulai meneliti pemikir-pemikir tersebut yang menurutnya memiliki pola pikir yang jauh berbeda dari pemikir-pemikir Islam Indonesia lainnya.

Wacana Islam liberal ini banyak menuai kontroversi yang bertubi-tubi, bahkan dalam perjalanannya, Islam liberal banyak menuai cemoohan, dan doktrin-doktrin negatif. Pada era Cak Nur belum dikenal istilah Islam liberal, bahkan apa yang dilakukan Cak Nur pada masa itu dalam mengutarakan gagasannya di berbagai tempat belum dikatakan sebagai gerakan Islam liberal. Karena pada saat itu wacana Islam liberal masih mengalami akomodasionis, sehingga pada saat itu belum muncul istilah Islam 
liberal, hanya saja saat itu Cak Nur dijuluki sebagai "pembaru pemikiran Islam." 41

Meskipun demikian hal itu menunjukkan ada sebuah proses pembaharuan pemikiran dalam Islam dengan cara berpikir bebas namun mendasar, dan karena itulah disebut pemikir liberal. Pemikir liberal seperti Cak Nur ini merupakan pemikir yang tidak begitu saja meninggalkan jauh dasar-dasar hukum dalam Islam. Namun, pada sejarahnya setiap gagasan yang dikeluarkan oleh Cak Nur selalu mengundang kontroversi. Semisal sebuah gagasan yang diutarakan dalam seminar Cak Nur mengatakan;

“Orang harus membedakan antara connotation (bahasa arab: mafhum) sekularisasi yang berarti pengetrapan sekularism dengan kata "sekularisasi" karena konteksnya berlainan. Ibaratnya kata "socialised medicine" bukan berarti pengetrapatan socialism." 42

Dalam penyampaian gagasan tersebut menuai protes dari berbagai kalangan, seperti protes yang dilakukan oleh H.M. Rasyidi dengan cara memeberikan analisa terhadap gagasan Cak Nur dalam sebuah karyanya yang berbentuk buku yang berjudul "Koreksi Tehadap Nurchlis Madjid Tentang "Sekularisasi"." Menurut Dr. HM. Rasyidi

Fikiran Drs. Nurcholis ini tidak benar. Socialised medicine sudah barang tentu berarti mengetrapkan sosialisme dalam pengobatan, yakni bahwa si pasien tidak membayar, karena pemerintah yang memakai sosialisme sebagai dasar, akan membayar ongkos-ongkos pengobatan itu. Betul di Inggirs dahulu adalah negeri kapitalis imperialis. Akan tetapi partai buruh yang memakai sejenis socialisme sebagai dasar (tidak sama dengan sosialisme Marxist), telah melakukan sistem socialised medicine tersebut. Di Amerika melakukan (kampiun penentang sosialisme), sepanjang pengetahuan saya belum melakukan sosialised medicine. Entah pada waktu yang akan datang. Dengan demikian nyatalah

4I Adian Husaini dan Nu'im Hidayat, Islam liberal, sejarah, konsepsi, penyimpangan, dan jawabannya, (Jakarta: Gema Insani, 2002), 42.

${ }^{42}$ H.M. Rasyidi, Koreksi Tehadap Nurchlis Madjid Tentang "Sekularisasi”, 8.

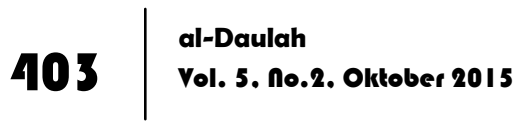


bahwa sekularisasi mempunyai hubungan erat dengan sekularisme, karena berarti pengetrapan sekularism. ${ }^{43}$

Hal tersebut menunjukkan ada sebuah proses wacana pemikiran yang sehat. Namun dalam hal ini Dr. Rasyidi belum memahami maksud yang ingin diterapkan oleh Cak Nur. Cak Nur dalam gagasan ini mencoba menunjukkan konsep kenegaraan dan pola pikir Islam yang seutuhnya dengan pendekatan pemahaman apologetik yang dicoba untuk ditawarkan.

Islam, dalam pandangan Syari'ati bukanlah agama yang hanya memperhatikan aspek spiritual dan moral atau hanya sekadar hubungan antara hamba dengan Sang Khaliq (Hablu min Allah), tetapi lebih dari itu, Islam adalah sebuah ideologi emansipasi dan pembebasan:

"Adalah perlu menjelaskan tentang apa yang kita maksud dengan Islam. Dengannya kita maksudkan Abu Zar; bukan Islamnya Khalîfah. Islam keadilan dan kepemimpinan yang pantas; bukan Islamnya penguasa, aristokrasi dan kelas atas. Islam kebebasan, kemajuan (progress) dan kesadaran; bukan Islam perbudakan, penawanan dan pasivitas. Islam kaum mujâhid; bukan Islamnya kaum ulama. Islam kebajikan dan tanggungjawab pribadi dan protes; bukan Islam yang menekankan dissimulasi (taqiyeh) keagamaan, wasilah ulama dan campur tangan Tuhan. Islam perjuangan untuk keimanan dan pengetahuan ilmiah; bukan Islam yang menyerah, dogmatis, dan imitasi tidak kritis (taqlîd) kepada ulama." 44

Selanjutnya, gambaran Islam pembebasan ditegaskan kembali oleh Syari'ati:

"Adalah tidak cukup dengan menyatakan kita harus kembali kepada Islam. Kita harus menspesifikasi Islam mana yang kita maksudkan: Islam Abu Zar atau Islam Marwan (bin. Affan), sang penguasa. Keduanya disebut Islam, walaupun sebenarnya terdapat perbedaan besar di antara keduanya. Satunya adalah

43 Ibid., 14.

${ }^{44}$ http://dunia.pelajar-Islam.or.id/dunia.pii/209/Islam-agama-pembebasan-ali-syariati.html 
Islam ke-khalîfah-an, istana dan penguasa. Sedangkan lainnya adalah Islam rakyat, mereka yang dieksploitasi dan miskin. Lebih lanjut, tidak cukup syah dengan sekadar berkata, bahwa orang harus mempunyai kepedulian (concern) kepada kaum miskin dan tertindas. Khalîfah yang korup juga berkata demikian. Islam yang benar lebih dari sekedar kepedulian. Islam yang benar memerintahkan kaum beriman berjuang untuk keadilan, persamaan dan penghapusan kemiskinan." 45

Menurut penulis apa yang dilakukan oleh Cak Nur tidaklah salah seperti apa yang diungkapkan oleh Dr. Rasyidi, sebab ada sebuah pengertian secara tersirat yang belum dipahami olehnya. Hal tersebut senada dengan apa yang dikatakan oleh salah satu mahasiswa yang pernah menerima kuliah dari Cak Nur dia mengatakan, "Mungkin dalam hal ini perlu ada sebuah perubahan istilah agar maksud yang ingin dicapai dapat tersampaikan". Saat itu menurutnya, apa yang ramai diperbincangkan mengenai sekularisasi dan slogan "Islam yes, partai Islam no!" merupakan kurangnya pemahaman terhadap apa yang ingin disampaikan oleh Cak Nur. ${ }^{46}$ Sehingga dalam hal ini menurut penulis, perlu ada sebuah penjelasan dari Cak Nur dengan menggunakan bahasa dan istilah yang lebih mudah dipahami oleh banyak kalangan.

Pemahaman Cak Nur terhadap gagasannya, tentang sekularisasi adalah menginginkan agar doktrin sakralisasi terhadap hal-hal yang seharusnya tidak perlu disakralkan, untuk dirubah menjadi proses desakralisasi. Sebab menurutnya hal yang perlu disakralkan hanyalah Tuhan, dan Tuhan itu sendiri hanyalah Allah. Pada dasarnya pendekatan apologetik yang tertuang dalam gagasannya merupakan pemahaman dasar dalam Islam, segala sesuatu hanya akan kembali kepada-Nya. Namun, kesalahan yang dilakukan oleh Cak Nur adalah penggunaan istilah-istilah yang kurang begitu familier di masyarakat, sehingga menyebabkan miss interpretative di kalangan masyarakat.

45 lbid.

${ }^{46}$ Nurcholis Madjid, Jejak Pemikiran dari Pembaharu Sampai Guru Bangsa, 75. 
Dalam hal ini beberapa pemikir yang telah dibahas pada pembahasan sebelumnya seperti Cak Nur dan Gus Dur adalah merupakan bagian dari pemikir Islam liberal, seperti yang dikatakan oleh Dr. Greg bahwa kedua tokoh tersebut merupakan penarik gerbong Islam liberal di Indonesia beserta kedua pemikir lainnya. Cak Nur dan Gus Dur adalah sosok pemikir liberal yang memiliki konsistensi dalam berpikir cukup tinggi, terutama dalam pemikirannya terhadap Islam liberal. Selain konsisten terhadap pemikiran yang bisa dikatakan liberal baik Cak Nur maupun Gus Dur, keduanya meiliki perhatian cukup mendalam terhadap pluralisme.

Pemikiran politik Cak Nur di Indonesia tidak jauh berbeda dengan Gus Dur. Walaupun Cak Nur dibesarkan oleh Masyumi ketika masih dalam status Mahasiswa, Cak Nur sama sekali tidak menunjukkan pola pikir seperti yang diterapkan oleh Masyumi. Dalam hal ini Cak Nur lebih banyak terhadap pola pikirnya sendiri, terlebih pasca ia menyelesaikan studinya di luar negeri. Salah satu contoh adalah gagasan pemikirannya yang bertema "Keharusan pembaharuan pemikirin Islam", yang mana di dalamnya sangat bertentangan dengan nilai-nilai dasar dan tujuan terbentuknya Masyumi. Dalam gagasan ini Cak Nur mencoba memilah antara agama dan negara, sebab menurut Cak Nur pemahaman Masyumi tentang keharusan berdirinya "Negara Islam" merupakan suatu distorsi. ${ }^{47}$ Hal tersebut memiliki pengaruh yang cukup besar terhadap politik Masyumi, dan dampaknya pun berimbas hingga sekarang. Masyumi pun kandas di tengah jalan dan cita-cita untuk mendirikan negara Islam pun karam di tengah arus badai pluralisme yang juga merupakan dasar dari pemikiran Cak Nur.

Dalam hal ini Cak Nur juga melakukan pemahaman dengan pendekatan apologhetik, dalam kamus ilmiah populer diartikan pemikiran mendalam dengan menggunakan pendekatan agama

${ }^{47}$ Marwan Saridjo, Cak Nur: Diantara Sarung dan Dasi \& Musdah Mulia Tetap Berjillbab, (Jakarta: Yayasan Ngali Aksara, 2005), 28-29. 
atau keyakinan. Sebagai contoh adalah pemahamannya terhadap sekularisasi yang mengarah pada desakralisasi. Kemudian menghasilkan sebuah slogan "Islam yes, partai Islam no!", tujuannya adalah agar ada suatu pemisahan antara agama dan negara, agar intelektual muda khususnya muslim di Indonesia tidak mengalami kejumudan dalam berpikir tentang Islam. Seperti tersebut sebelumnya, bahwa selama ini di Indonesia mengalami pengekangan pemikiran Islam yang diberikan kepada intelektual muda khususnya muslim di Indonesia. Sehingga hal yang seharusnya tidak perlu disakralkan menjadi sakral karena doktrin publik para tokoh-tokoh agama. Menurut Cak Nur dalam buku Dr. Greg menyatakan, yamg pantas disakralkan adalah Tuhan itu sendiri, selain Tuhan maka perlu ada suatu desakralisasi agar tidak mengalami kerancuan dalam berpikir dan tidak mengalami kesesatan.

\section{Ruang Lingkup Sosial Abdurrahman Wahid Menurut Pandangan Greg Barton}

Gus Dur merupakan putra pertama dari kiai Wahid Hasyim, yang merupakan cucu dari kiai Hasyim Asy'ari masa kecilnya ia habiskan di lingkungan pesantren. "Pesantren adalah sekolah agama Islam yang menyediakan asrama bagi murid-muridnya." 48 Dalam bukunya, Dr. Greg menjelaskan masa-masa di mana Gus Dur hidup dan tinggal. Menurut Dr. Greg Gus Dur hidup dalam ruang lingkup keluarga Islam yang tradisionalis, atau seperti tersebut sebelumnya yaitu hidup di lingkungan pesantren.

1. Dibesarkan di pesantren dan perpolitikan (1940-1963)

Gus Dur dilahirkan di Denanyar dekat kota Jombang, mengenai tanggal lahir Gus Dur tidak banyak orang mengetahui secara pasti ${ }^{49}$. Saat berada di Istana Negara banyak orang yang mengunjungi Gus Dur untuk merayakan hari kelahirannya pada

\footnotetext{
${ }^{48}$ Greg Barton, Biografi Gus Dur: The Authorized Biography of Abdurrahman Wahid, 25.

${ }^{49}$ lbid.
} 
tanggal 4 agustus, saat itu bertepatan pada hari jum'at 4 agustus 2000 Gus Dur merayakan hari kelahirannya di Istana Negara. Namun, banyak yang tak sadar bahwa sebenarnya tanggal tersebut bukan merupakan tanggal lahirnya. Gus Dur memang dilahirkan pada hari keempat bulan kedelapan, akan tetapi perlu diketahui bahwa tanggal itu adalah menurut kalender Islam, yakni dilahirkan pada bulan Sya'ban, bulan kedelapan dalam penanggalan Islam. Yaitu jatuh pada tanggal 7 September. ${ }^{50}$

Pada tahun 1954, setahun setelah menamatkan sekolah dasarnya dan memulai Sekolah Menengah Ekonomi Pertama (SMEP), ia terpaksa mengulang karena ketidak berhasilannya dalam ujian..$^{51}$ Pada tahun itu pula ayahandanya meninggal dunia, akhirnya ibundanya pun terpaksa berjuang sendiri demi menghidupi keluarganya (Gus Dur). Karena ekonomi yang tidak mumpuni, dan kurang berhasilnya Gus Dur dikirim ke Yogyakarta untuk melanjutkan sekolah (SMP), dia dititipkan pada seorang teman ayahnya yaitu Kiai Junaidi, yang merupakan seorang kiai dari gerakan modernis Muahammadiyah yang menduduki jabatan pada Majelis Tarjih Muhammadiyah. Seperti tradisi pada umumnya masyarakat tradisionalis, terutama keluarga Gus Dur yang begitu kental akan darah seorang kiai, Gus Dur pun diharuskan melengkapi pendidikannya di pesantren. Untuk melengkapi pendidikan Gus Dur itu, maka diaturlah agar ia dapat masuk pesantren, dan akhirnya Gus Dur dikirim ke pesantren alMunawwir untuk belajar bahasa Arab. ${ }^{52}$ Pada tahun berikutnya setelah mengeyam pendidikan diberbagai sekolah mulai dari sekolah dasar, sekolah menengah pertama, hingga Madrasah Aliyah (SMA) Gus Dur kemudian melanjutkan ke Perguruan Tinggi.

\footnotetext{
50 lbid.

51 Ibid., 49.

52 lbid.
} 


\section{Pendidikan di luar negeri (1963-1971)}

Pada pertengahan tahun 1960-an Gus Dur sangat berambisi untuk melanjutkan studinya di perguruan tinggi luar negeri, pada saat itu Gus Dur begitu senang dan merasa bersemangat untuk melanjutkan studinya di perguruan tinggi tersebut, yaitu al-Azhar, merupakan perguruan tinggi idaman umat muslim muda pada saat itu. ${ }^{53}$ Namun pada tahun 1964 ketika Gus Dur memasuki perguruan tinggi tersebut, yang dirasakannya adalah kekecewaan sebab ia harus masuk kelas pemula terlebih dahulu, mengapa demikian karena menurut Gus Dur pada kelas pemula tersebut ia harus mengulang pelajarannya ketika masih duduk di bangku aliyah atau pesantren. Ketika berada di Kairo Gus Dur berusia 25 (dua puluh lima) tahun, disana ia menghabiskan waktu dengan banyak membaca dan menonton film-film prancis, akan tetapi untuk dapat menonton film Gus Dur harus bersembunyisembunyi untuk keluar dari asrama.

Pada saat berada di Kairo Gus Dur lebih banyak mendapatkan kekecewaan daripada kepuasan. Pasca studinya di Kairo Gus Dur mendapat tawaran beasiswa di Baghdad, disalah satu universitas yang ada disana. ${ }^{54}$ Walaupun Gus Dur merasa kecewa dengan studi formalnya di Kairo, namun ia banyak menarik manfaat dari lingkungan sosial dan intelektual disana. Ia berada di Baghdad cukup lama sampai sekitar akhir tahun 1960an. Saat ia berada di Baghdad ia memiliki seorang teman yang merupakan seorang pemikir liberal dari komunitas kecil Yahudi Irak di Baghdad, yang bernama Ar-Rahmadani. ${ }^{55}$ Pertemanan Gus Dur ini terlihat aneh memang, sebab Gus Dur adalah sosok yang dikenal tergolong kaum tradisionalis. Hal ini mungkin yang menyebabkan adanya sebuah pemikiran yang tergolong baru dari Gus Dur bagi penganut tradisionalis, pemikiran yang begitu plural dan dapat dikategorikan dalam ranah pemikir liberal.

\footnotetext{
53 Ibid., 89.

54 lbid., 102.

55 lbid., 108.
} 
Pada pertengahan tahun 1971, Gus Dur telah menyelesaikan studi di Baghdad, kemudian Gus Dur mencoba untuk melanjutkan studi di Eropa, mula-mula Gus Dur mencari informasi di salah satu universitas yang ada di Belanda yaitu Universitas Leiden..$^{56}$ Namun, lagi-lagi Gus Dur harus merasakan kekecewan karena ditolak untuk masuk dan melanjutkan studi di universitas tersebut. Alasan universitas tersebut tidak mau menerima Gus Dur adalah karena Gus Dur merupakan alumni dari perguruan tinggi Timur Tengah, sedangkan Universitas Leiden memiliki peraturan yang menyebutkan bahwa bagi setiap mahasiswa yang pernah mengeyam studi formal berasal dari universitas Islam yang ada di Timur Tengah tidak dapat diterima untuk melanjutkan studi di Universitas Leiden Belanda. Karena kegagalannya tidak dapat masuk ke universitas tersebut, akhirnya Gus Dur kembali ke Jakarta.

\section{Metode Pemikiran Abdurrahman Wahid Menurut Pandangan Greg Barton}

Tokoh kedua yang juga sama-sama dikagumi oleh Dr. Greg adalah Gus Dur, sosok Gus Dur menurutnya merupakan sosok yang begitu sederhana, hangat, dan santai di tengah kepadatan aktivitasnya sehari-hari. ${ }^{57}$ Ketika Gus Dur meninggalkan Jombang untuk belajar ke luar negeri, ia seorang pemuda yang tengah bergulat dengan masalah bagaimana Islam bisa mengadakan perubahan di dunia. ${ }^{58}$ Masa dewasanya, ia pernah terpukau oleh Islamisme yang radikal. Tujuh tahun kemudian ia kembali ke tanah air sebagai orang yang penuh komitmen terhadap pemahaman liberal mengenai Islam. Perkembangan intelektual Gus Dur dibentuk oleh pendidikan Islam klasik dan pendidikan barat modern. ${ }^{59}$ Faktor-faktor ini merupakan prasyarat baginya

\footnotetext{
${ }^{56}$ Ibid., I I I.

57 lbid., 4-6.

58 lbid., |3|.

59 lbid., 134.
} 
untuk mengembangkan ide-ide liberalnya. Gus Dur adalah seorang intelektual Indonesia yang menonjol dan sangat disegani. ${ }^{60}$ Peran seorang Gus Dur dalam dunia Islam dan perpolitikan di Indonesia banyak menimbulkan kebingungan, sebagian besar berasal dari peran banyak wajah yang dimainkannya dalam masyarakat Indonesia. Lebih tepatnya, kebingungan itu muncul karena pada satu sisi Gus Dur dikenal sebagai seorang figur religius dan pada sisi lain di tafsirkan banyak orang, khususnya di pusat-pusat metropolitan dan antara kelas menengah terdidik Indonesia sebagai politisi yang sekular atau intelektual liberal. Salah satu hal yang mudah dipahami adalah Gus Dur adalah penyeru pluralisme dan toleransi, pembela kelompok minoritas, khususnya Cina Indonesia, juga penganut kristen dan kelompok-kelompok lain yang tidak diuntungkan pada masa pemerintahan Soeharto. ${ }^{61}$

Pandangan liberal lainnya terhadap Gus Dur oleh Dr. Greg adalah tanggapan Gus Dur yang mendukung sepenuhnya gagasan Cak Nur, menurut Gus Dur gagasan (pidato Cak Nur) tersebut memang sangat diperlukan di masa sekarang dan sampai kapanpun dengan menggunakan istilah dinamisasi, dengan alasan bahwa legalisme Islam yang dicoba untuk dituangkan sebagai doktriner di Indonesia terbukti telah gagal, dalam menggairahkan masyarakat. ${ }^{62}$ Selain itu, pada pertengahan tahun 1970-an Gus Dur menulis dan membuat jelas bahwa gerakan pembaharuan pemikiran Islam yang didengungkan oleh Cak Nur merupakan suatu langkahnmaju menuju sebuah pemikiran Islam yang lebih relevan. ${ }^{63}$ Dr. Greg juga menggambarkannya pada perhatian Gus Dur yang mendalam terhadap partai-partai politik Islam dan

\footnotetext{
${ }^{60}$ Greg Barton, Pengantar: Prisma Pemikiran Gus Dur, xx.

${ }^{61}$ Ibid., xxii.

${ }^{62}$ Greg Barton, Gagasan Islam Liberal di Indonesia, 428.

${ }^{63}$ lbid., 428-429.
} 
politik-kepartaian Islam dengan tidak diperkenankannya melahirkan sentimen sektarian dalam masyarakat. ${ }^{64}$

Para tokoh ini merupakan pemikir liberal yang memiliki tingkat ketenaran yang tinggi dibandingkan teman-teman pemikir lainnya. ${ }^{65}$ Kedua tokoh ini mengambil jalur pemikiran yang sama untuk mewujudkan perubahan pemikiran terhadap Islam agar tidak terjadi stagnasi. Pemikirannya terbukti mampu merubah sebagian pandangan pemikiran intelektual muda pada masa lalu hingga kini. Selain mampu membawa perubahan paradigma berpikir Islam monoton, pemikiran kedua tokoh ini mampu mempengaruhi arah politik di Indonesia. ${ }^{66}$ Terbukti dengan kalahnya partai politik Islam dan sedikitnya pendukung partai politik Islam, hal itu menunjukkan gagasan kedua pemikir ini mampu mempengaruhi pola pikir masyarakat luas. ${ }^{67}$

Dari berbagai ulasan tersebut, metode pemikiran Gus Dur adalah menggunakan pendekatan sosio kultural yang mana metode tersebut digunakan Gus Dur untuk merubah pola pikir masyarakat tradisional pada masa itu. ${ }^{68}$ Salah satu cara yang digunakan oleh Gus Dur adalah berkecimpung kedalam organisasi NU, meskipun awalnya Gus Dur pernah mengecam organisasi tersebut dengan mengatakan organisasi orang tua yang berjalan begitu lamba dalam menghadapi realitas sosial di masyarakat.

\footnotetext{
${ }^{64}$ Ibid., 429.

${ }^{65}$ Greg Barton, Biografi Gus Dur: The Authorized Biography of Abdurrahman Wahid, 134.

${ }^{66} \mathrm{http}: / / \mathrm{ww}$.perspektif.net/article.php?article_id $=885$

${ }^{67}$ Greg Barton, Sebenarnya Indonesia Negara Sekular; Dalam, Mengapa Partai Islam Kalah, Perjalanan Politik Islam Dari Pra Pemilu 1999 Sampai Pemilihan Presiden, (Jakarta: Alfabet, 1999, 345. download/Filsafat\%2520Negara\%2520Gus\%2520Dur/Bab\%252003\%2520Pemikiran\%2520 Politik\%2520lslam\%2520Gus\%2520Dur.doc + metode + pemikiran + gus + dur\&cd = 4\&hl=id $\& \mathrm{ct}=\mathrm{clnk} \& \mathrm{gl}=\mathrm{id} \& \mathrm{client}=$ firefox $-\mathrm{a}$
} 


\section{Pola Pikir Abdurrahman Wahid Menurut Pandangan Greg Barton}

Abdurrahman adalah seorang intelektual Indonesia yang menonjol dan sangat disegani. ${ }^{69}$ Tokoh yang sudah lebih dari 15 tahun menjabat Ketua Umum Pengurus Besar Nahdlatul Ulama (NU), organisasi kaum tradisionalis, ini sering menghiasi halamanhalaman koran. Dalam beberapa tahun terakhir Gus Dur populer digambarkan sebagai tukang bikin teka-teki, sulit ditebak dan sering mengejutkan langkahnya. ${ }^{70}$ Bahkan manuver-manuvernya sering dikatakan tidak jelas arahnya sehingga dianggap tidak konsisten.

Pada tanggal 20 oktober 1999 dipilih menjadi presiden keempat Republik Indonesia. ${ }^{71}$ Dr. Greg mengatakan "tak pernah terpikirkan oleh saya bahwa ia akan menjadi presiden." 72 Memang dia akan memiliki peran penting dalam civil society dalam peralihan era Soeharto. Namun demikian, tampaknya benar-benar tidak masuk akal bila membayangkannya menjadi presiden. Bahkan seorang pendeta Eka Darmaputera merasa "gemas" dengan sikap Gus Dur yang mau menerima tawaran menjadi presiden. ${ }^{73}$ Menurut Pdt. Eka, mestinya Gus Dur tetap berada pada posisi netral dan bebas dari ikatan posisi politik seperti itu. Pdt. Eka memberikan analogi tehadap pencalonan Gus Dur menjadi presiden dengan mengibaratkan memaksakan benda berharga masuk kedalam karung yang terlalu kecil. ${ }^{74}$

Begitu banyak riuh suara burung yang mengkritik apa yang telah dan akan dilakukan Gus Dur dalam berbagai hal, namun di sisi lain orang yang beramai-ramai mengkritik, memuji, dan

${ }^{69}$ Greg Barton, Memahami Abdurrahman Wahid; Dalam Pengantar Prisma Pemikiran Gus Dur, (Yogyakarta: Lkis, 2000), xx.

70 Greg Barton, Abdurrahman Wahid Dan Toleransi Keberagamaan; Dalam Gila Gus Dur Wacana Pembaca Abdurrahman Wahid, (Yogyakarta: LkiS, 2000), 84.

7l Ahmad Suaedy dan Ulil Abshar Abdalla (ed), Gila Gus Dur; Wacana Pembaca Abdurrahman Wahid, 12.

${ }^{72}$ Greg Barton, Biografi Gus Dur: The Authorized Biography of Abdurrahman Wahid, h. 12.

${ }^{73}$ Abdallah (ed), Gila Gus Dur; Wacana Pembaca Abdurrahman Wahid, xi.

${ }^{74}$ Ibid., 26. 
bahkan mencemoohnya itu tidak begitu paham dengan apa yang akan terjadi. Terkadang berbagai prediksi dari berbagai kalangan tidak sesuai dengan apa yang dilakukan Gus Dur. Gus Dur memiliki beberapa konsep pemikiran yang banyak disebutkan dikalangan masyarakat.

Konsep pemikiran Gus Dur tak jauh beda dengan pembahasan sebelumnya, masih seputar hal-hal yang berbau liberal. Pluralisme atau dalam kalangan masyarakat dikenal dengan sikapnya yang memiliki toleransi yang begitu besar dalam berbagai hal terutama antar umat beragama, sehingga dikatakan sebagai pemikir yang memiliki pola pikir plural. Dalam menggambarkan pola pikir Gus Dur Dr. Greg mengamatinya dari tulisan-tulisan Gus Dur yang berkaitan dengan itu. Menurut Dr. Greg apa yang ditulis oleh Gus Dur itu merupakan cerminan diri dari pola pikir Gus Dur dalam menyikapi perubahan dalam masyarakat, baik dari sisi Islam maupun politik Islam. Menurut Dr. Greg dari sinilah pola pikir Gus Dur dapat dilihat, dari berbagai tulisan dan sample tokoh yang ia tulis dalam artikelartikelnya, secara tidak langsung Gus Dur meniru apa yang dilakukan oleh tokoh yang ia tulis dalam beberapa karyanya.

\section{Pluralisme}

Tidak sedikit kesulitan yang ditimbulkan oleh perubahan terus-menerus dalam sudut penglihatan yang disajikan oleh tulisan-tulisan yang dimuat dalam buku ini. Dengan hanya mempelajari buku ini, mungkin sulit atau bahkan tidak mungkin ditarik sebuah kesan umum yang jelas tentang bentuk pemikiran yang berkembang dalam diri penulis. Namun sebuah warna jelas sekali telah menampakkan diri; keterbukaan untuk menelusuri berbagai cara berpikir dan kesediaan untuk mencari kebenaran dimanapun juga ia berada. Kalau dengan warna umum ini saja 
dapat dicari manfa'at penerbitan buku kumpulan tulisan ini, sudah terbalaslah jerih payah menerbitkannya. ${ }^{75}$

Menurut Dr. Greg, secara keseluruhan baris ketiga dari tulisan di atas mengemukakan sikap pluralis yang mewarnai hampir segenap tulisan Gus Dur; "kebenaran untuk menemukan kebenaran di mana pun juga." 76

Selama hampir tiga dekade, Gus Dur banyak menulis artikel mengenai perlunya toleransi dan saling pemahaman antar komunitas agama. ${ }^{77}$ Hal tersebut ditulis dalam artikel Dr. Greg.

Dalam menggambarkan pola pikir plural Gus Dur, Dr. Greg mengambil sample dengan mengacu pada kasus-kasus yang digambarkan oleh Gus Dur dengan contoh-contoh figur yang ada dalam beberapa esai. Dari banyak contoh Dr. Greg mengambil bebarapa esai, yang ditulis oleh Gus Dur, antara lain:

\section{Rasionalitas Kiai Adlan}

Gus Dur mengatakan, pluralisme mengakar bukan dalam bagaimana seseorang bertindak tetapi dalam bagaimana orang itu berpikir. ${ }^{78}$ Oleh sebab itu, pribadi-pribadi yang ia tulis dalam esaiesai di Tempo (media cetak, Red.) tahun 1980 adalah orang-orang yang memperoleh reputasi membahayakan dari sudut pandang lahiriyah. Salah satunya Kiai Adlan.

Kiai Adlan merupakan murid pertama K.H. Hasyim Asy'ari (kakek Gus Dur). Dalam esainya (Gus Dur), yang diberi judul "Rasionalitas Kiai Adlan" memunculkan isu mengenai mengpai Kiai Adlan memasuki dunia tarekat diusia tua. Padahal ketika ia masih menjadi murid Hasyim Asy'ari, ia enggan untuk mengikuti apa yang gurunya lakukan seperti masuk dalam dunia tarekat, meskipun demikian ia masih menghormati gurunya yang begitu

\footnotetext{
${ }^{75}$ Greg Barton, Gagasan Islam Liberal, 395

$76 \mathrm{lbid}$.

77 Greg Barton, Abdurrahman Wahid dan Toleransi Keberagamaan, Dalam Gila Gus Dur; Wacana Pembaca Abdurrahman Wahid, 95.

${ }^{78}$ Ibid., 396.
} 
peduli terhadap tarekat. Namun, bukan sisi tarekatnya yang dimaksud oleh Gus Dur.

Ternyata dalam hal ini sudut pandangan lahiriyah saja untuk dapat menangkap tindakan yang secara lahiriah itu berbentuk pembalikan sikap. Harus dimengerti sebab-sebabnya diambil sikap seperti itu, harus didekati rasionalitas itu sendiri. Adalah ceroboh untuk begitu saja menilai sesuatu tindakan sebagai pembalikan sikap, sebelum jelas-jelas diketahui apakah ia benar pembalikan atau bukan.

Dalam kasus Kiai Adlan Ali, konsistensi dalam berpikirlah yang menjadi sebab dari apa yang tampak sebagai pembalikan sikap itu. Kiai Hasyim dulu menentang ekses-ekses tarekat, bukan tarekatnya. ${ }^{79}$

Kemudian Gus Dur memberikan sebuah konklusi dari apa yang dilakukan oleh Kiai Adlan, yang dijelaskan selanjutnya dalam paragraf penutup di esai tersebut. Yaitu akar-akar toleransi itulah yang mendorong untuk tidak terlalu cepat memberi penilaian dan yang mengembangkan ambivalensi sehat terhadap bentuk-bentuk eksternal. ${ }^{80}$ Apa yang disampaikan Gus Dur dalam esai tersebut merupakan gambaran toleransi yang dilakukan oleh sosok Kiai Adlan terhadap permasalahan yang terjadi masa itu.

Konklusi seperti tersebut diatas adalah sebagai berikut yang juga masih merupakan bagian dari esai di atas, Gus Dur mengatakan;

Sekarang persoalannya sudah lain sekali, begitu mungkin jalan pikiran Kiai Adlan. Orang tidak bergairah menjalankan ajaran agama di luar lingkup ketarekatan. Apakah akan kita biarkan mereka tidak bersembahyang, hanya karena takut eksesekses tarekat itu sendiri? Bagaimana pertanggung jawaban kita dihadapan Allah kelak? Mana yang lebih perlu, mengajak orang agar bersembahyang, ataukah meributkan ekses-ekses tarekat?

\footnotetext{
${ }^{79}$ Ibid., 396-397.

80 lbid.
} 
Kalau dipahami jalan pikiran ini, akan menjadi jelas pula mengapa Kiai Adlan dapat mendamaikan antara keterlibatan dirinya dalam gerakan tarekat dan kecintaan (yang menghasilkan ketundukan) dirinya kepada mendiang gurunya, Kiai Hasyim, walaupun ketundukan itu tidak hanya dalam pengertian literer perintah sendiri saja, tetapi juga ketundukan untuk mengembangkannya dalam kasus yang sama sekali berbeda. Ketundukan didalam (inner obidience) yang tampak sebagai pengingkaran di luar (outer disobidience). ${ }^{81}$

Dr. Greg mengambil sebuah kesimpulan pemikiran Gus Dur tentang pluralisme, dari sebuah tulisan yang ditulis oleh Gus Dur. salah satunya adalah esai yang menceritakan sosok Kiai Adlan yang mengunakan pemikiran plural dalam menanggapi permasalahan di depannya. Toleransi dan ditunjukkan oleh Kiai Adlan itulah yang dianggap salah satu pemikiran plural oleh Gus Dur, dan kemudian oleh Dr. Greg dijadikan sebuah acuan dalam penelitiannya tentang Gus Dur dan Islam liberal.

\section{Dinamisasi}

Dinamisasi merupakan salah satu gagasan Gus Dur yang dipandang oleh Dr. Greg sebagai pola pikir liberal Gus Dur dalam Islam. Dr. Greg memilah dengan berbagai sub judul yang ditulis dalam disertasinya, dengan mengutip dari tulisan-tulisan Gus Dur, di antaranya:

\section{Dinamisme dan modernisme pesantren}

Gagasan dinamisme Gus Dur ini berawal dari kekecewaannya terhadap kegagalan-kegagalan pesantren atau Islam tradisional dalam meng-apresiasikan pemikiran Islam..$^{82}$ Gus Dur menganggap bahwa pesantren tidak mampu membawa sebuah perubahan pemikiran kearah yang lebih maju. Maka dari itu, Gus Dur berupaya mendefinisikan bentuk responsi secara

\footnotetext{
${ }^{81}$ Ibid.

${ }^{82}$ Greg Barton, Gagasan Islam Liberal, 370.
} 
kreatif terhadap tuntutan-tuntutan dan tantangan-tantangan modernitas serta untuk menghadapi Islam abad ke-20.

Dalam upaya merealisasikan gagasanya, Gus Dur menggunakan istilah dinamisme. ${ }^{83}$ Dengan kata asal "dinamis" dalam bahasa Indonesia, yang juga merupakan adopsi bahasa Inggris dynamic.

Dinamisme dalam bahasa Indonesia diartikan bukan saja sebagai kualitas yang energetik dan hidup, melainkan juga sebagai kemampuan mengadaptasi dan merespon persoalan-persoalan masyarakat secara kreatif. Gus Dur memanfaatkan pengertian itu secara keseluruhan dengan menggunakan kata dinamis (dinamisasi, Red.). "Dinamisasi dan Modernisasi Pesantren" merupakan artikel yang ditulis oleh Gus Dur dan disampaikan dalam Seminar Pesantren di tahun 1973. Dalam seminar tersebut Gus Dur menyampaikan,

Sebelum menginjak pokok-pokok persoalan yang ditentukan oleh judul pembicaraan ini, terlebih dahulu haruslah dijelaskan apa yang dimaksud dengan penggunaan kata dinamisasi dan modernisasi. Dinamisasi, pada asasnya mencakup dua buah proses yaitu penggalakan kembali nilai-nilai hidup positif yang telah ada, disamping mencakup pula pergantian nilai-nilai lama itu dengan nilai-nilai baru yang dianggap lebih sempurna. Proses penggantian nilai itu dinamai modernisasi. Jelaslah dari keterangan ini, bahwa pengertian modernisasi sebenarnya telah terkandung dalam kata dinamisasi.

Sedangkan kata dinamisasi itu sendiri, dalam penggunaanya disini akan memiliki konotasi/mafhum "perubahan ke arah penyempurnaan keadaan," dengan menggunakan sikap hidup dan peralatan yang telah ada sebagai dasar. Dikemukakan prinsip itu disini, karena ada keyakinan, konsep-konsep yang dirasa asing oleh pesantren, akan menghadapi hambatan luar biasa nantinya. Kita percaya, pendekatan untuk memperoleh penerimaan dari 
pesantren sendiri, dalam jangka panjang akan memberikan hasil yang lebih baik daripada konsep manapun juga. ${ }^{84}$

Hal itu disampaikan guna merubah pola pikir pesantren (tradisional) yang menurut Gus Dur perlu ada sebuah perubahan, agar tidak menjadi hambatan sebuah pemikiran baru yang nantinya akan muncul sebagai perubahan pemikiran, khususnya bagi Islam.

Meskipun yang diinginkan Gus Dur adalah sebuah perubahan pemikiran dalam Islam, dengan menggunakan konsep dinamisasi-nya, yang dalam pengertian secara literer mengaju kepada perubahan secara menyeluruh terhadap ajaran-ajaran Islam tradisional. Namun tidak demikian menurut pemahaman Gus Dur, Dr. Greg mengatakan dinamisasi yang disimpulkan oleh Gus Dur tidak seperti "melempar bayi ke kolam air," artinya tidak dengan cara membuang ajaran-ajaran tradisional demi tuntutan perubahan. ${ }^{85}$ Gus Dur memaknai konsepsi dinamisasi bukan sekedar proses yang canggih dan hebat atau sebuah kolaborasi antara Islam tradisional dengan modern. Tetapi sebuah pembuktian terhadap masyarakat bahwa Islam tradisional tidak pernah menjadi sesuatu yang statis. Simpul kata, Gus Dur menganggap bahwa dinamisasi bukan sebagai tanggapan abad ke20 terhadap tekanan-tekanan modernitas, melainkan ekspresi terbaik dalam Islam tradisional yang adaptif dan fleksibel.

Berbagai contoh tentang bermacam sosok yang ditulis oleh Gus Dur merupakan sebuah diskripsi nyata yg terjadi di masyarakat tentang betapa pentingnya pluralisasi dalam segala hal. Terlebih toleransi antar umat beragama.

Pluralisme bukan suatu barang impor dari luar negeri. Pluralisme adalah suatu yang biasa di dalam masyarakat Indonesia," ujarnya. Hal ini tercermin dengan diakuinya

85 lbid., 374. 
semboyan Bhinneka Tunggal Ika, yang digagas oleh Mpu Tantular pada abad ke-6. ${ }^{86}$

Hal itu dikemukakan oleh Gus Dur dalam sebuah orasinya pada 2008 desember dalam acara "Orasi Catatan Akhir Tahun" di Hotel Santika Jakarta, dan hal itu diamini oleh Romo Magnis Suseno yang juga hadir dalam orasi tersebut. Namun, Romo Magnis mengakui bahwa saat ini masih ada tendensi di masyarakat yang tidak mengakui pluralisme dan tidak dapat menerima perbedaan keyakinan. ${ }^{87}$ Kemudian ditegaskan kembali oleh Romo tersebut, "ini berbahaya, kita harus belajar menerima perbedaan."

Sementara itu, Gus Dur dalam pidatonya yang lain pada suatu acara yang diadakan oleh The Wahid Institute mengatakan,

Pluralisme yang menjadi isi buku dan roh dirinya diambil dari keputusan Muktamar Nahdlatul Ulama (NU) pada 1935. Muktamar memutuskan untuk menjalankan syariat Islam tetapi tidak perlu negara Islam di Indonesia. ${ }^{88}$

Pada saat itu adalah bertepatan dengan hari ulang tahun The Wahid Institute sekaligus launching karya tulis terbaru Gus Dur yang berjudul Islamku, Islam Anda, Islam Kita. Di dalamnya banyak membahas tentang esensi dan implementasi pluralisme dalam kehidupan berbangsa dan negara di dalam masyarakat.

Salah satu tindakan Gus Dur yang masih hangat diperbincangkan ialah mengenai UU Pornografi, Gus Dur dan istrinya menolak keras akan UU tersebut, bahkan dalam sebuah karnaval besar di Jakarta yang di ikuti para penentang RUU APP, Sinta Nuriyah (istri Gus Dur) beserta artis-artis ibukota seperti Inul, dan artis lainnya, serta WTS menjadi simbol penentang RUU APP. ${ }^{89}$ Selain itu, Gus Dur juga sempat mengutarakan kritik yang

\footnotetext{
${ }^{86} \mathrm{http}: / /$ www.kompas.com/read/xml/2008//2/28/I5345448/orasi.gus.dur.tekankan.pentingnya.pl uralisme

${ }^{87} \mathrm{lbid}$.

${ }^{88} \mathrm{http}: / /$ aidctranslate.wordpress.com/

${ }^{89}$ Abdurrahman Nusantari, Ummat Menggugat Gus Dur, (Bekasi: Aliansi Pecinta Syari'at, 2006), 34.
} 
sangat keras terhadap peraturan-peraturan yang ada di Indonesia termasuk peraturan tentang Pornografi. Saat itu kritik tersebut dilontarkan ketika Gus Dur sedang diwawancarai oleh komunitas utan kayu atau lebih di kenal dengan JIL, Gus Dur mengatakan;

Gusdur berkata, "Perda Tangerang maupun RUU APP yang kini diributkan, harus jelas dulu siapa yang merumuskan dan menentukannya. Pelacuran memang dilarang agama, tapi siapakah pelacur itu? Jangan-jangan, yang kita tuduh pelacur justru bukan pelacur. Dari dulu memang ada dua hal yang perlu kita perhatikan sebelum menetapkan UU. Pertama, siapa yang merumuskan. Kedua, apakah dia memiliki hak antara pelaksana dan pihak lain. Contoh paling jelas adalah soal definisi Pornografi. Ketika tidak jelas ini dan itu pornonya, yang berhak menentukan adalah Mahkamah Agung. ${ }^{90}$

Hal merupakan suatu wujud dari apa yang diutarakan Gus Dur dalam pertemuan Muktamar NU pada tahun 1935.

Selain Liberal Gus Dur dianggap orang nyeleneh dan asalasalan dalam mengucapkan sesuatu, dan dianggap melanggar hukum, seperti misalnya ketika Gus Dur mengatakan bahwa ICMI merupakan organisasi sektarian. ${ }^{91}$ Selain itu Gus Dur juga mengemukakan bahwa ICMI adalah salah satu kalangan Islam eksklusif yang tidak menghargai pluralisme agama.92 Bagi Gus Dur komunitas seperti ICMI ini adalah suatu komunal yang dibentuk era rezim soeharto, yang pada saat itu digandeng oleh soeharto sebagai alat kontrol terhadap para cendikiawan muslim (Islam moderat) untuk membantu mempertahankan jabatannya sebagai presiden. ${ }^{93}$ Sebab, pada saat itu gerakan Islam militan yang menginginkan formalisasi agama dalam negara (Indonesia), sangat kuat dan cukup besar semangatnya dalam mewujudkan hal

\footnotetext{
$90 \mathrm{lbid}$

${ }^{91}$ Ibid., 2.

92 Syamsul Bakri dan Mudhofir, Jombang Kairo, Jombang Mesir: Sintesis Pemikiran Gus Dur Dan Cak Nur Dalam Pembaharuan Islam di Indonesia, (Solo: Tiga Serangkai 2004), 36.

${ }^{93}$ Greg Barton, Gagasan Islam Liberal di Indonesia, 500-50I.
} 
tersebut. Kehadiran ICMI dalam sebuah sistem negara ini, diharapkan dapat membantu sebagai penengah atau monitor untuk mengatasi laju gerakan Islam militan pada saat itu. Menurut Gus Dur apa yang dilakukan oleh soeharto merupakan suatu jalan buntu dalam mengatasi masalah yang terjadi di era soeharto.

Saya khawatir strategi seperti ini akan menghancurkan... Muslim moderat akan menang seandainya sistemnya bebas, tapi masalahnya soeharto justru sedang memberi bantuan pada kelompok-kelompok militan.... kita butuh waktu untuk mengembangbiakkan toleransi agama yang penuh berdasarkan kebebasan beragama. Tapi yang terjadi sebaliknya, soeharto kini tengah membuka pintu bagi kelompok-kelompok muslim tertentu, yang kebanyakan adalah kaum militin yang mengajukan Islam sebagai solusi untuk segala problema modernisasi. ${ }^{94}$

Menurut Gus Dur apa yang dilakukan oleh Soeharto merupakan suatu tindakan yang bodoh, bahkan secara berani dia memunculkan statement dengan mengatakan "Stupiditing dan karena soeharto tidak mau melihat siapa pun yang tidak berada dalam pengawasannya," hal itu merupakan suatu pandangan Gus Dur terhadap sikap soeharto yang dirasa aneh, yang didapatkan dari hasil wawancara Dr. Greg dengan Gus Dur.

Maksud dari Gus Dur adalah seharusnya organisasi seperti itu tidak perlu ada, karena hanya menimbulkan suatu penyekatan antara satu kelompok dengan kelompok lain, dan akan merapuhkan sendi-sendi toleransi. Dan satu hal yang tidak diinginkan oleh Gus Dur adalah terjadinya sektarianisme, sebab ICMI yang mengaku sebagai Islam moderat memiliki ambisi yang menyerupai gerakan Islam militan. ${ }^{95}$

Salah satu langkah konkrit yang dilakukan oleh Gus Dur dalam menerapkan konsep pemikirannya adalah dengan cara menarik mundur kekuatan NU dari segala jenis aktifitas politik

\footnotetext{
94 lbid.

95 Ibid., 499.
} 
kepartaian. ${ }^{96}$ Wujud konkrit yang dilakukan oleh Gus Dur ketika ia menduduki jabatan penting di NU adalah menarik mundur NU dari kontes perpolitikan di PPP (partai persatuan pembangunan), hal ini menunjukkan sikap konsisten Gus Dur untuk menerapkan konsep pluralismenya. Hal ini mendapatkan kritik yang begitu pedas dengan menyatakan bahwa dengan mundurnya NU dari PPP, dan pentas politik kepartaian khususnya Islam, maka NU tidak akan memperoleh posisi independensi yang lebih luas dan kehilangan produktivitasnya serta akan kehilangan pengaruh politik di Indonesia. ${ }^{97}$

Hal ini menunjukkan betapa besarnya peran Gus Dur dalam dunia politik dan keIslaman di Indonesia. Sehingga tidak heran jika apa yang dilakukan oleh Gus Dur sering mendapat kritik yang begitu pedas, dan bahkan seolah ingin menjatuhkan eksistensi Gus Dur di ranah politik Indonesia, dan Islam khususnya. Dalam menjalakankan misinya tersebut, yaitu mewujudkan pluralisme di Indonesia, Gus Dur menggunakan NU, pemimpin-pemimpin keagamaan, dan pemimpin masyarakat bukan Muslim sebagai kendaraan serta kompo $\backslash$ nen yang membantu terciptanya toleransi dalam beragama, berbangsa, dan bernegara. Hal tersebut pun mendapat dukungan cukup besar seperti tersebut sebelumnya.

\section{Pemikiran Abdurrahman Wahid tentang Islam Liberal dan Eksistensi Politik Islam di Indonesia Menurut Greg Barton}

Sama halnya dengan apa yang senantiasa dilakukan oleh Gus Dur, sosok seorang Gus Dur yang tidak jauh beda kontroversialnya dengan Cak Nur. Di satu sisi kedua pemikir ini sama-sama memiliki pola pikir yang mirip bahkan terkadang cenderung lebih berani dan terus terang dalam menyampaikan gagasannya dibanding sosok seorang Cak Nur. Dalam segi bahasa pun Gus Dur lebih cenderung dengan menggunakan bahasa sehari-hari yang bisa dikatakan bahasa tersebut kurang ilmiah dan

${ }^{97}$ lbid., 497. 
terkadang banyak menimbulkan persepsi dan konotasi negatif. Ada yang mengatakan kalau Gus Dur itu "nyeleneh", karena begitu nyelenehnya hingga apa yang dikatakan oleh Gus Dur dianggap asal-asalan. Padahal pada dasarnya yang dikatakan oleh Gus Dur adalah suatu hal yang memiliki arti begitu tajam dan dalam.

Dalam disertasinya, Dr. Greg lebih sering mengambil sikap pluralisme Gus Dur sebagai contoh dari pola pikir liberal Gus Dur dalam Islam khususnya di Indonesia. Dalam hal ini Gus Dur dikenal sebagai bapak pluralisme Indonesia, terlebih ada yang memyebutnya bahwa Gus Dur adalah bapak pluralisme dunia.

Suatu hal yang perlu dicermati dalam hal ini adalah sikap Gus Dur yang sering mengundang kontroversi, sebagai salah satu contoh adalah gagasannya yang mengatakan bahwa "Tuhan tidak perlu dibela", secara implisit makna gagasan tersebut tidaklah salah. Sebab, pada hakikatnya Tuhan adalah Maha segalanya dan sanggup berbuat apa saja, meskipun tanpa harus dibela.

Contoh kasus ini bisa dikatakan tidak begitu usang diperdebatkan, yaitu tentang Undang-Undang Pornografi (selanjutnya disebut UU Pornografi), meskipun menuai bantahan dari berbagai kalangan akhirnya RUU Pornografi telah sah menjadi UU. Saat itu di suatu tempat terjadi demo besar-besar tentang penolakan RUU Pornografi yang dihadiri para penentang RUU APP, Sinta Nuriyah (istri Gus Dur) beserta artis-artis ibukota seperti Inul, dan artis lainnya, serta WTS menjadi simbol penentang RUU APP.98 Selain itu Gus Dur juga sempat mengeluarkan kritik terhadap legislator (pembuat UU) atas rancangan undang-undang tersebut. Saat itu kritik tersebut dilontarkan ketika Gus Dur sedang diwawancarai oleh komunitas utan kayu atau lebih dikenal dengan JIL, Gus Dur mengatakan;

Gus Dur berkata, "Perda Tangerang maupun RUU APP yang kini diributkan, harus jelas dulu siapa yang merumuskan dan

\footnotetext{
${ }^{98}$ Abdurrahman Nusantari, Ummat Menggugat Gus Dur, 34.
} 
menentukannya. Pelacuran memang dilarang agama, tapi siapakah pelacur itu? Jangan-jangan, yang kita tuduh pelacur justru bukan pelacur. Dari dulu memang ada dua hal yang perlu kita perhatikan sebelum menetapkan UU. Pertama, siapa yang merumuskan. Kedua, apakah dia memiliki hak antara pelaksana dan pihak lain. Contoh paling jelas adalah soal definisi Pornografi. Ketika tidak jelas ini dan itu pornonya, yang berhak menentukan adalah Mahkamah Agung. ${ }^{99}$

Dalam kasus ini Gus Dur mencoba mengklarifikasi terlebih dahulu sebelum RUU tersebut menjadi UU yang sah. Dalam hal ini sikap Gus Dur yang menyatakan bahwa Tuhan tidak perlu dibela adalah relevan dengan apa yang terjadi dengan kenyataan saat itu. Sebab, kebanyakan pendukung UU Pornografi ini adalah gerakan-gerakan Islam yang mengatas namakan gerakan sebagai pembela agama. Kita tahu agama merupakan suatu kepercayaan yang datangnya dari Tuhan, lantas jika gerakan tersebut menyatakan membela Islam maka secara otomatis gerakan tersebut seakan-akan ingin membela Tuhan yang "harga diri-Nya (Islam)" merasa terinjak-injak apabila Pornografi masih berlangsung. Kritik Gus Dur tersebut jelas bahwa memang pada hakikatnya Tuhan mampu melakukan semua yang Ia inginkan, sehingga menurut hemat Gus Dur "Tuhan tidak perlu dibela". Dipertegas oleh Gus Dur seharusnnya yang pantas dibela adalah hamba-hambanya, kaum-kaum yang tertindas, dan umat Islam yang merasa dirugikan atas terbentuknya UU Pornografi serta umat beragama lainnya yang mungkin juga akan terkena imbasnya jika UU Pornografi tersebut disahkan. Selain itu seperti tersebut sebelumnya Gus Dur juga tidak menginginkan adanya formalisasi, ideologisasi, dan syari'atisasi Islam dalam suatu negara. Alasannya adalah, apabila terlalu radikal ingin memformalisasi, ideologisasi, dan syari'atisasikan dengan melakukan penafsiran terhadap teks al Qur'an secara literal, akan 
menimbulkan implikasi luas. 100 Sehingga akan mengakibatkan terabaikannya pluralitas masyarakat, apabila hal tersebut terjadi. ${ }^{101}$

Hal tersebut menunjukkan suatu konsistensi terhadap penerapan pemikirannya tentang pluralisme. Gagasan yang begitu jelas terlontar ialah tentang pernyataanya bahwa pluralisme bukanlah suatu hal yang baru di Indonesia, yang diutarakan oleh Gus Dur dalam pidatonya di suatu acara yang bertema "orasi catatan akhir tahun", yang kemudian gagasan tersebut diamini oleh salah seorang pemimpin agama Kristen yang hadir pada saat itu.

Pada dasarnya baik Cak Nur maupun Gus Dur, keduanya saling mendukung adanya sebuah toleransi dalam masyarakat agar tidak menimbulkan sektarianisme dan komunalisme dalam Islam yang nantinya jika hal tersebut terwujud maka akan menimbulkan suatu disfungsi pemikiran khususnya dalam Islam, sebab sektarianisme terhadap komunal akan mengungkung pola pikir pengikutnya dengan doktrin-doktrin yang seharusnya tidak perlu terjadi, agar pluralitas masyarakat tidak terabaikan. Islam liberal memang secara kasat mata tidak memiliki hubungan dengan politik Islam, sebab kita ketahui bahwa Islam liberal sangat anti dengan politik, terutama politik yang mengatasnamakan Islam sebagai dasar atau tameng hukum untuk dapat memperoleh masa yang cukup, karena kita ketahui juga Indonesia memiliki penduduk yang mayoritas menganut agam Islam sebagai dasar keyakinan dalam beragama. Tidak diragukan lagi bahwa tidak mungkin seorang pemikir liberal menduduki jabatan politik atau terjun ke dalam ranah poitik, khususnya politik Islam, baik politik Islam, politik partai, maupun politik kepartaian Islam. Selain itu, dalam hal pemikiran, Islam liberal tidak pernah memberikan suatu kontribusi apapun yang bersifat positif (menurut politik Islam), dalam membantu memperjuangkan apa yang ingin dicapai dari perjalanan politik Islam. Mengapa demikian, sebab konstruksi

${ }^{100}$ Abdurrahman Wahid, Islamku, Islam Anda, Islam Kita, (Jakarta: The Wahid Institute, 2006), xv. I0I Ibid. 
pemikiran Islam liberal begitu kontras dengan pola pikir yang diterapkan dalam politik Islam (Indonesia). Seperti telah dijelaskan sebelumnya, tujuan dari segala tujuan politik Islam adalah untuk memformalisasi, ideologisasi, dan syari'atisasikan Islam dalam sebuah negara (Indonesia). Jika memang demikian, jelas bahwa hal tersebut bertentangan dengan cita-cita Islam liberal. Sebab tujuan dari Islam liberal adalah untuk memisahkan antara agama dan negara, serta mewujudkan pluralisme dalam beragama, berbangsa, dan bernegara.

Islam yes, partai Islam no!, hingga kini masih terasa dampaknya, seperti tersebut sebelumnya organisasi Islam yang menginginkan formalisasi syari'at kandas, dan tidak pernah terwujud hingga sekarang. Meski demikian upaya untuk mencapur adukkan hal itu masih tetap ada dan terjadi, meskipun secara jelas negara Islam tidak pernah terwujud. Mengenai hal itu tokoh selanjutnya yang mampu mengendus isyarat-isyarat yang mengarah pada pembentukan negara Islam adalah Gus Dur. Suatu kasus yang nyata adalah upaya Gus Dur untuk menggagalkan pembentukan UU Pornografi yang masih terasa hangat di telinga kita. Selain itu, saat Gus Dur menjabat sebagai puncak pimpinan di Indonesia ini Gus Dur berhasil mewujudkan cita-cita pluralisme yang selama ini juga diinginkan oleh Cak Nur. Gus Dur berhasil mengangkat harkat kaum-kaum minoritas seperti China, Tionghoa, dan sebagainya agar dapat diterima di Indonesia. Wujud dari perhatian tersebut diflorkan oleh Gus Dur dalam sebuah acara "orasi akhir tahun" seperti tersebut sebelumnya.

Bagi Gus Dur agama selain memiliki dimensi keimanan dan ketuhanan yang sakral dan mutlak, juga memiliki dimensi kebudayaan/kultural yang melahirkan berbagai simbol atau ritus. ${ }^{102}$ Sikapnya yang begitu konsisten terhadap pluralisme membuat banyak orang menaruh simpati dan berlindung padanya, khusunya kaum minoritas atau yang juga disebut

${ }^{102}$ Al-Zastrow Ng, Gus Dur Siapa Sih Sampeyan?, (Jakarta:, Erlangga, 1999), 267.

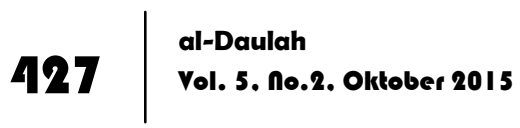


sebagai mustadh'afin. Tak heran jika beberapa waktu lalu Gus Dur begitu keras menentang pengesahan RUU APP untuk dijadikan sebagai suatu regulasi untuk memberantas pornografi. Dalam hal ini golongan formalisme Islam merasa berhasil untuk mewujudkan cita-citanya sedikit demi sedikit. Karena dengan disahkannya RUU APP menjadi UU Pornografi gerakan Islam formalisme, fundamentalisme, dan gerakan yang sejalan dengan itu merasa diuntungkan, sebab gerakan tersebut merupakan pendukung terkuat terhadap terbentuknya regulasi tersebut. Sehingga pandangan Gus Dur ini banyak menuai kontroversi dan menjadi sebuah perdebatan publik di manapun, baik media masa maupun media cetak. Sejalan dengan pemikiran Cak Nur, Gus Dur pun sangat menolak adanya sebuah formalisasi Islam dalam negara terutama di Indonesia. Dengan alasan "Sampai hari ini belum juga saya temukan. Sehingga saya sampai pada kesimpulan bahwa Islam memang tidak memiliki konsep tentang bagaimana negara dibuat dan dipertahankan." ${ }^{103}$ Hal tersebut menunjukkan sikap pluralisme Gus Dur terhadap agama dan negara, selain itu Gus Dur juga sempat megutarakan bahwa Tuhan tidak perlu dibela, spontan hal tersebut membuat telinga para gerakan formalisme Islam merasa gatal dan seperti kebakaran jenggot. Sampai akhirnya kritik yang begitu pedas diluncurkan oleh golongan fundamentalisme Islam dalam sebuah tulisan yang berjudul umat menggugat Gus Dur. Di mana di dalamnya berisikan segala sesuatu yang berkenan dengan Gus Dur yang dianggap melenceng dari rel syari'at.

Gus Dur dikenal sebagai sosok pemberani dan tidak pernah takut akan apapun, serta berbicara apa adanya dengan seenaknya. Karena sikapnya yang terkadang tidak terkontrol dalam mengomentari sesuatu ataupun mengeluarkan sebuah gagasan, menurut Dr. Greg di situlah letak kelemahan Gus Dur sehingga dengan mudah digoyahkan oleh musuh. Sebagai contoh adalah

${ }^{103}$ Abdurrahman Wahid, Islamku, Islam Anda, Islam Kita, xvi. 
ketika ia berada di posisi puncak pimpinan, seperti tersebut sebelumnya, menurut Dr. Greg Gus Dur jatuh karena kurangnya dukungan dari berbagai fraksi serta keputusannya yang terlalu tergesa-gesa dalam menjatuhkan sesuatu. Karena itulah, Gus Dur mudah sekali untuk dijatuhkan dan hingga akhirnya lengser. Namun, meskipun demikian cita-citanya untuk mengangkat kaum minoritas terwujud dan mampu mengubah tatanan politik di Indonesia, terbukti seorang keturunan Cina ataupun Tionghoa juga dapat mencari nafkah tanpa harus merasa tertekan seperti masa orde baru, bahkan dalam ranah birokrasi kelompok minoritas juga dapat menduduki posisi yang sama dalam sebuah kelembagaan negara.

\section{Penutup}

Pandangan Greg Barton terhadap Nurcholis Madjid (Cak Nur) tentang Islam liberal dan eksistensi politik Islam di Indonesia adalah Cak Nur memiliki pola pikir liberal yang bisa dikatakan begitu kuat atas dasar latar belakang kehidupannya yang begitu mendukung yaitu berkecimpung di organisasi modern Islam seperti HMI. Selain itu Cak Nur melanjutkan studi formalnya ke luar negeri, yaitu Chichago, di mana negara tersebut notabene adalah tempat para pemikir liberal barat berkumpul. Jadi, wajar apabila sepulangnya ia ke Indonesia, memiliki pola pikir yang sedikit berbeda dan bahkan liberal. Metode pemikiran Cak Nur dalam menganalisa sesuatu khususnya Islam menggunakan metode Double Movement, yaitu pola pikir sekular dan modern, sehingga Cak Nur dijuluki sebagai pemikir liberal dan pemikirannya tersebut banyak mempengaruhi pola pikir dalam dunia perpolitikan, khususnya politik Islam di Indonesia. Seperti runtuhnya Masyumi, serta hilangnya kepercayaan masyarakat terhadap organisasi politik Islam (partai politik Islam) pada era Cak Nur.

Menurut Greg Barton pemikiran Abdurrahman Wahid (Gus Dur) tentang Islam liberal dan eksistensi politik Islam di Indonesia 
adalah tidak berbeda jauh dengan Cak Nur, keduanya konsisten berada pada jalur liberal yang sama-sama menolak akan formalisasi syari'at. Pelajaran tentang berpikir liberal Gus Dur didapat dari sebuah pertemanannya dengan seorang Yahudi Iraq ketika ia melakukan studi di Baghdad. Sedangkan di Kairo, Gus Dur mendapatkan pemikiran Islam secara utuh, meskipun sedikit mengecewakan. Metode yang dilakukan oleh Gus Dur adalah dengan melakukan pendekatan sosio kultural. Jadi, Gus Dur merupakan sosok yang berasal dari keluarga tradisional yang memiliki pola pikir plural dan dinamis, yang juga termasuk dalam kategori liberal. Selain itu menurut Greg Barton, Gus Dur merupakan tokoh Islam liberal yang mampu menembus ranah politik Indonesia dan mengubah tatanan politik saat itu.

\section{Daftar Pustaka}

Bakri, Syamsul dan Mudhofir. Jombang Kairo, Jombang Mesir: Sintesis Pemikiran Gus Dur Dan Cak Nur Dalam Pembaharuan Islam di Indonesia. Solo: Tiga Serangkai, 2004.

Barton, Greg. Gagasan Islam Liberal di Indonesia. Jakarta: Paramadina, 1999.

-------. Sebenarnya Indonesia Negara Sekular; Dalam, Mengapa Partai Islam Kalah, Perjalanan Politik Islam Dari Pra Pemilu 1999 Sampai Pemilihan Presiden. Jakarta: Alfabet, 1999.

-------. Abdurrahman Wahid dan Toleransi Keberagamaan, Dalam Gila Gus Dur; Wacana Pembaca Abdurrahman Wahid. Yogyakarta: LkiS, 2000.

-------. Memahami Abdurrahman Wahid; Dalam Pengantar Prisma Pemikiran Gus Dur. Yogyakarta: Lkis, 2000.

- Biografi Gus Dur: The Authorized Biography of Abdurrahman

Wahid, Penerjemah: Lie Hua. Yogyakarta: LkiS, 2006.

http://74.125.153.132/search?q=cache:EO4McS2d-

rEJ:www.khatibul-

umam.com/download/Filsafat $\% 2520$ Negara $\% 2520$ Gus $\% 2520$

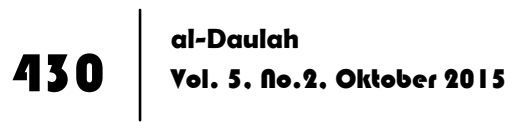


Dur/Bab\%252003\%2520Pemikiran\%2520Politik\%2520Islam\%2 520 Gus $\% 2520$ Dur.doc + metode+pemikiran+gus+dur\&cd=4\&hl $=\mathrm{id} \& \mathrm{ct}=\mathrm{clnk} \& \mathrm{gl}=\mathrm{id} \& \mathrm{client}=$ firefox-a

http://aidctranslate.wordpress.com/

http://dunia.pelajar-Islam.or.id/dunia.pii/209/Islam-agama-

pembebasan-ali-syariati.html

http://public.kompasiana.com/2009/03/06/cak-nur-yes-liberal-no/

http://www.alIslamu.com/index.php?option=com_content\&task=vi

ew\&id=41\&itemid $=10$

http://www.apcss.org/core/bios/barton/barton.htm

http://www.arrahmah.com/index.php/blog/read/1376/liberalisasi-

Islam-di-Indonesia

http://www.harianterbit.com/artikel/rubrik/artikel.php?aid=64471

http://www.kompas.com/read/xml/2008/12/28/15345448/orasi.gus.

dur.tekankan.pentingnya.pluralisme

http://www.perspektif.net/article.php?article_id=885

http://www.perspektif.net/article.php?article_id=885

http://www.tempointeraktif.com/hg/narasi/2004/05/30/nrs,2004053

0-05,id.html

Husaini, Adian, dan Nu'im Hidayat. Islam Liberal, sejarah, konsepsi, penyimpangan, dan jawabannya. Jakarta: Gema Insani, 2002.

Madjid, Nurcholis. Islam Kemodernan dan Ke Indonesiaan. Bandung: Mizan, 1993.

-------. Jejak Pemikiran dari Pembaharu Sampai Guru Bangsa. Yogyakarta: Pustaka Pelajar, 2003.

Ng, Al-Zastrow. Gus Dur Siapa Sih Sampeyan?. Jakarta: Erlangga, 1999.

Nusantari, Abdurrahman. Ummat Menggugat Gus Dur. Bekasi: Aliansi Pecinta Syari'at, 2006.

Pusat Bahasa Departemen Pendidikan Nasional. Kamus Besar Bahasa Indonesia. Jakarta: Balai Pustaka, Cet. III, 2005.

Rasyidi, H.M. Koreksi Tehadap Nurchlis Madjid Tentang "Sekularisasi". Jakarta: Bulan Bintang, 1972. 
Saridjo, Marwan. Cak Nur: Diantara Sarung dan Dasi \& Musdah Mulia Tetap Berjilbab. Jakarta: Yayasan Ngali Aksara, 2005.

Suaedy, Ahmad dan Ulil Abshar Abdalla (eds). Gila Gus Dur: Wacana Pembaca Abdurrahman Wahid. Yogyakarta: Lkis, 2000.

Wahid, Abdurrahman. Islamku, Islam Anda, Islam Kita. Jakarta: The Wahid Institute, 2006. 